\title{
Peningkatan Keterampilan Menulis Cerita Sederhana dengan Menerapkan Metode Latihan Terbimbing dan Media Teks Lagu
}

\author{
Sujono \\ SDN Wonokusumo VII/46 Surabaya \\ Jl. Wonosari Lor Baru No.21 Kecamatan Semampir, Surabaya \\ sujonowk7@gmail.com
}

\begin{abstract}
This study aims to improve students' simple story writing skills by applying guided training methods and utilizing song text media. The subjects of this research were 37 students of class III-A with the research location at SD Negeri Wonokusumo VI / 45 Surabaya. This research was conducted through a two-cycle action mechanism. Based on data analysis, from this study it can be concluded that the Skills of Writing Simple Stories for Grade III-A students of SD Negeri Wonokusumo VI / 45 Surabaya increased by $20.44 \%$ after participating in learning Simple Story Writing through guided training methods with song text media. The average result of the pre-action Simple Story Writing test was 61 (rounding down from 61.30) and in the first cycle the average result was 69 (rounding up from 68.62) then in cycle II the average results were obtained. an average of 77 (the result is rounded down from 77.05 ) or an increase of $15.75 \%$ from cycle I. The average result of the Simple Story Writing test score shows that learning Simple Story Writing through the guided practice method with song text media on Class III-A students of SD Negeri Wonokusumo VI / 45 Surabaya can improve and succeed.
\end{abstract}

Keywords: Writing Skills, Short Stories, Guided Exercises, Song Text Media

\begin{abstract}
Abstrak
Penelitian ini bertujuan untuk meningkatkan keterampilan menulis cerita sederhana pada siswa dengan menerapkan metode latihan terbimbing dan memanfaatkan media teks lagu. Subjek penelitian ini adalah siswa kelas III-A yang berjumlah 37 orang dengan lokasi penelitian yang dilaksanakan di SD Negeri Wonokusumo VII/46 Surabaya. Penelitian ini dilaksanakan melalui mekanisme dua siklus tindakan. Berdasarkan analisis data, dari penelitian ini dapat ditarik kesimpulan bahwa Keterampilan Menulis Cerita Sederhana siswa Kelas III-A SD Negeri Wonokusumo VII/46 Surabaya mengalami peningkatan sebesar 20,44\% setelah mengikuti pembelajaran Menulis Cerita Sederhana melalui metode latihan terbimbing dengan media teks lagu. Hasil ratarata tes Menulis Cerita Sederhana pratindakan sebesar 61 (hasil pembulatan ke bawah dari 61,30) dan pada siklus I diperoleh hasil rata-rata sebesar 69 (hasil pembulatan ke atas dari 68,62) kemudian pada siklus II diperoleh hasil rata-rata sebesar 77 (hasil pembulatan ke bawah dari 77,05) atau meningkat sebesar 15,75\% dari siklus I. Perolehan hasil rata-rata nilai tes Menulis Cerita Sederhana ini menunjukkan bahwa pembelajaran Menulis Cerita Sederhana melalui metode latihan terbimbing dengan media teks lagu pada siswa Kelas III-A SD Negeri Wonokusumo VII/46 Surabaya dapat meningkat dan berhasil.
\end{abstract}

Kata kunci: Keterampilan Menulis, Cerpen, Latihan Terbimbing, Media Teks Lagu

Copyright (c) 2020 Sujono

$\triangle$ Corresponding author: Sujono

Email Address: sujonowk7 @ gmail.com (Jl. Wonosari Lor Baru No.21 Kecamatan Semampir, Surabaya)

Received 28 Januari 2020, Accepted 30 Desember 2020, Published 30 Desember 2020

\section{PENDAHULUAN}

Keterampilan Menulis Cerita Sederhana yang diajarkan di sekolah-sekolah selama ini menggunakan metode konvensional. Peran guru amat dominan dalam proses pembelajaran. Siswa kurang aktif dan sering kali metode ini menimbulkan kebosanan bagi siswa dalam pembelajaran Menulis Cerita Sederhana sehingga karya yang dihasilkan siswa kurang maksimal. Cerpen yang dibuatnya kurang menarik karena bahasa yang digunakan monoton, dan pengembangan ide atau 
gagasan kurang bervariasi. Hal ini dapat dilihat dari kesesuaian isi cerpen dengan tema, pengembangan topik, dan diksi yang belum mendapat perhatian dari siswa.

Guru sebagai penyampai materi kepada siswa harus dapat menyampaikan materi yang akan dibahas dengan metode dan media yang tepat dan menarik. Hal tersebut akan berdampak pada keberhasilan siswa dalam mengikuti pembelajaran dan mengerjakan tugas yang diberikan guru.

Keprofesionalan seorang guru dituntut demi lancarnya proses belajar mengajar. Ada tiga persyaratan utama yang harus dimiliki oleh seorang guru agar menjadi guru yang baik, yaitu menguasai (1) bahan ajar (2) keterampilan pembelajaran, dan (3) evaluasi pembelajaran. Dalam penguasaan keterampilan pembelajaran guru dituntut untuk menggunakan berbagai strategi pembelajaran. Strategi pembelajaran yang tepat dan dapat menarik perhatian siswa sehingga menciptakan suasana pembelajaran yang menyenangkan dan dapat mencapai tujuan pembelajaran yang diharapkan.

Pembelajaran Menulis Cerita Sederhana dalam penelitian ini menggunakan metode latihan terbimbing karena keterampilan menulis bukanlah semata-mata milik golongan orang yang berbakat menulis, melainkan dengan latihan yang sungguh-sungguh keterampilan itu dapat dimiliki oleh siapa saja. Keterampilan menulis merupakan proses belajar yang memerlukan ketekunan berlatih, semakin rajin berlatih, keterampilan menulis akan meningkat. Begitu juga dengan keterampilan Menulis Cerita Sederhana, untuk dapat menulisnya diperlukan usaha yang keras dan latihan terbimbing secara terusmenerus untuk menghasilkan cerpen yang baik. Peran guru sebagai motivator, fasilitator, sekaligus inspirator bagi siswa sangat diperlukan dalam hal ini yaitu memberikan latihan terbimbing kepada siswa dalam menulis kreatif cerpen.

Media yang digunakan dalam pembelajaran Menulis Cerita Sederhana yaitu teks lagu. Teks lagu merupakan sebuah naskah yang berisi lirik lagu yang berisi rangkaian kata yang merupakan ungkapan pikiran dan perasaan penyair. Pemilihan teks lagu sebagai media dalam pembelajaran Menulis Cerita Sederhana didasarkan pada alasan-alasan berikut: (1) pada usianya yang beranjak remaja kebanyakan siswa Kelas III-A menyukai lagu-lagu, sehingga dengan media ini diharapkan dapat menstimulus siswa untuk menghasilkan karya terbaiknya dan dapat menciptakan suasana belajar yang menyenangkan, (2) lagu merupakan sarana hiburan yang menyenangkan dan dapat menciptakan kepuasan, kebahagiaan dan keharuan bagi yang menikmatinya, (3) teks lagu berisi rangkaian kata indah yang mengisahkan sebuah cerita, baik mengenai kehidupan, pengalaman ataupun sebuah peristiwa, dengan teks lagu tersebut dapat diketahui alur dan temanya yang akan mempermudah siswa dalam Menulis Cerita Sederhana.

Media memegang peran penting dalam pembelajaran karena dengan adanya media siswa dapat menangkap penjelasan yang disampaikan guru dengan mudah, begitu juga dengan media yang digunakan dalam pembelajaran Menulis Cerita Sederhana dengan media teks lagu ini. Siswa diharapkan dapat meningkatkan kemampuannya menuangkan ide-ide atau pengalamannya ke dalam sebuah karya sastra yaitu cerita pendek dengan mudah dan dapat menghasilkan karya yang baik. 
Beberapa penelitian mengenai keterampilan Menulis Cerita Sederhana telah banyak dilakukan. Berdasarkan beberapa penelitian yang telah dilakukan dapat disimpulkan bahwa penelitian tindakan kelas tentang keterampilan Menulis Cerita Sederhana telah banyak dilakukan, namun metode-metode dan media yang digunakan berbeda-beda. Metode dan media yang telah digunakan antara lain karya wisata, pengalaman pribadi sebagai basis melalui pendekatan keterampilan proses dan pemodelan. Hal tersebut memberi kemungkinan untuk menemukan metode-metode yang lain untuk dijadikan penelitian lebih lanjut. Penelitian ini akan mencoba metode latihan terbimbing dengan media teks lagu untuk meningkatkan keterampilan siswa dalam Menulis Cerita Sederhana.

Keterampilan Menulis Cerita Sederhana melalui metode latihan terbimbing dengan media teks lagu diasumsikan dapat mengatasi permasalahan siswa dalam pembelajaran keterampilan Menulis Cerita Sederhana. Oleh karena itu, peneliti melakukan penelitian tindakan kelas sekaligus sebagai bahan penyusunan skripsi dengan judul Peningkatan Keterampilan Menulis Cerita Sederhana melalui Metode Latihan Terbimbing dengan Media Teks Lagu Siswa Kelas III-A SD Negeri Wonokusumo VII/46 Surabaya.

\section{Kajian Pustaka}

\section{Hakikat Menulis Cerita Sederhana}

Menuli merupakan suatu keterampilan berbahasa yang dipergunakan untuk berkomunikasi secara tidak langsung, tidak tatap muka dengan orang lain (Tarigan, 1986:3). Komunikasi tidak langsung ini dilakukan dengan menggunakan media tulis, dengan menggunakan lambang-lambang bahasa. Menulis merupakan suatu kegiatan produktif dan ekspresif. Menulis Cerita Sederhana pada hakikatnya merujuk pada kegiatan mengarang, dan mengarang termasuk tulisan kreatif yang penulisannya dipengaruhi oleh hasil rekaan atau imajinasi pengarang. Menulis Cerita Sederhana merupakan cara menulis yang paling selektif dan ekonomis. Cerita dalam cerpen sangat kompak, tidak ada bagiannya yang hanya berfungsi sebagai embel-embel. Tiap bagiannya, tiap kalimatnya, tiap katanya, tiap tanda bacanya, tidak ada bagian yang sia-sia, semuanya memberi saham yang penting untuk menggerakkan jalan cerita, atau mengungkapkan watak tokoh, atau melukiskan suasana. Tidak ada bagian yang ompong, tidak ada bagian yang berlebihan (Diponegoro 1994:6).

Dalam hal kreativitas Menulis Cerita Sederhana, Tamsir (dalam Endraswara 2003:239) memberikan petunjuk bahwa penulis ibarat kamerawan yang membidik perjalanan panjang kehidupan manusia atau sesuatu yang dimanusiakan. Pendapat itu memberikan gambaran bahwa penulis cerpen harus tanggap terhadap lingkungan dan perubahan waktu. Pengalaman pribadi, pengamatan atas kejadian-kejadian di sekitar kita, dari membaca buku atau menonton film, bahkan dari mimpi bisa menjadi ide cerita yang mampu menggerakkan imajinasi untuk berkreasi membuat cerpen.

Selanjutnya Siregar dalam Gie (2002:197) menyatakan bahwa cerita adalah ekspresi yang menggunakan kata-kata atas suatu kejadian atau peristiwa yang dialami manusia. Cerita selamanya akan menyangkut manusia atau makhluk dan hal lain yang diperinsankan (dipersonifikasikan). Kejadian itu berlangsung pada saat seseorang tersebut berinteraksi dengan manusia lain dan alam 
sekelilingnya. Wujud dari interaksi itu dilahirkan dengan hal-hal yang dinyatakan dari pikiran dan perasaan dan hal-hal yang dinyatakan dengan perbuatan.

Wiyanto (2005:96) mengemukakan bahwa Menulis Cerita Sederhana harus banyak berkhayal karena cerpen memang karya fiksi yang berbentuk prosa. Peristiwa-peristiwa yang terjadi dalam cerpen hanya direkayasa pengarangnya. Demikian pula para pelaku yang terlibat dalam peristiwa itu. Waktu, tempat, dan suasana terjadinya peristiwa pun hanya direka-reka oleh pengarangnya. Oleh karena itu, cerpen (dan semua cerita fiksi) disebut cerita rekaan.

Cerita dalam cerpen meskipun khayal, ceritanya masih masuk akal sehingga mungkin saja terjadi. Bahan baku cerpen memang bisa berasal dari kisah yang benar-benar terjadi dalam masyarakat. Bisa juga cerita itu berasal dari kisah yang benar-benar dialami sendiri oleh pengarangnya yang diolah sedemikian rupa dalam bentuk cerpen menjadi cerita fiksi, cerita khayal, atau cerita rekaan. Namun, ada beberapa cerpen yang ceritanya tidak masuk akal, ceritanya benarbenar hasil imajinasi pengarangnya yang jauh dari kenyataan.

Trianto (dalam Kholifah 2006:19) menyebutkan bahwa tulisan yang bersifat kreatif merupakan tulisan yang bersifat apresiatif dan ekspresif. Apresiatif maksudnya melalui kegiatan menulis kreatif orang dapat mengenali, menyenangi, menikmati, dan mungkin menciptakan kembali secara kritis berbagai hal yang dijumpai dalam teks-teks kreatif karya orang lain dengan caranya sendiri dan memanfaatkan berbagai hal tersebut ke dalam kehidupan nyata. Ekspresif dalam arti bahwa kita dimungkinkan mengekspresikan atau mengungkapkan berbagai pengalaman/berbagai hal yang menggejala dalam diri kita untuk dikomunikasikan kepada orang lain melalui tulisan kreatif sebagai sesuatu yang bermakna. Salah satu teks bersifat kreatif adalah teks cerpen.

Berdasarkan uraian menulis kreatif cerpen yang disampaikan di atas, dapat diketahui bahwa Menulis Cerita Sederhana merupakan proses kreatif yang melahirkan pikiran, perasaan, secara ekspresif dan apresiatif. Peristiwa, pelaku, waktu, tempat, dan suasana yang terjadi dalam cerpen hanya bersifat rekaan atau khayal.

Sebuah cerpen tersusun atas unsur-unsur pembangun cerita yang saling berkaitan erat antara satu dengan yang lainnya. Keterkaitan antara unsur-unsur pembangun cerita tersebut membentuk totalitas yang bersifat abstrak. Koherensi dan keterpaduan semua unsur cerita yang membentuk sebuah totalitas amat menentukan keindahan dan keberhasilan cerpen sebagai suatu bentuk ciptaan sastra. Unsur-unsur dalam cerpen terdiri atas :

a. Alur atau Plot

Pengertian alur dalam cerita pendek atau dalam karya fiksi pada umumnya adalah "rangkaian cerita yang dibentuk oleh tahapan-tahapan peristiwa sehingga menjalin suatu cerita yang dihadirkan oleh para pelaku dalam suatu cerita" (Aminuddin 1987:83). Menurut Suharianto (1987:28) alur atau plot yakni cara pengarang menjalin kejadian-kejadian secara beruntun dengan memperhatikan hukum sebab akibat sehingga merupakan kesatuan yang padu, bulat, dan utuh".

Dari pendapat-pendapat tersebut dapat peneliti simpulkan bahwa alur atau plot adalah jalinan 
peristiwa secara beruntutan dalam cerita dengan memperhatikan hubungan sebab akibat sehingga cerita itu merupakan kesatuan yang padu, bulat dan utuh.

b. Tokoh dan Penokohan

Tokoh cerita (charakter), menurut Abrams (dalam Nurgiyantoro 1994:165), adalah orang-orang yang ditampilkan dalam suatu karya naratif. Atau drama, yang oleh pembaca ditafsirkan memiliki kualitas moral dan kecenderungan tertentu seperti yang diekspresikan dalam ucapan dan apa yang dilakukan dalam tindakan.

Tokoh adalah individu rekaan yang mengalami peristiwa dalam cerita atau perlakuan dalam cerita (Sudjiman dalam Faozan 2002:20). Tokoh dalam cerpen bersifat fiktif. Sudjiman juga mengemukakan pembagian tokoh dalam cerita dapat dilihat dari fungsi dan cara penampilannya.

c. Latar atau Setting

Latar atau setting adalah tempat, waktu, dan suasana terjadinya peristiwa dalam cerita (Wiyanto 2005:82). Selanjutnya Nurgiyantoro (2005:217) menyebutkan bahwa latar memberikan pijakan cerita secara konkret dan jelas. Hal ini penting untuk memberikan kesan realistis kepada pembaca, meciptakan suasana tertentu yang seolah-olah sungguh-sungguh ada dan terjadi. Setting bukan hanya menunjukkan tempat dan waktu tertentu tetapi juga hal-hal yang hakiki dari suatu wilayah, sampai pada macam debunya, pemikiran rakyatnya, kegilaan mereka, gaya hidup mereka, kecurigaan mereka dan sebagainya (Sumardjo 1991:76). Dari pendapat-pendapat tersebut dapat disimpulkan bahwa latar (setting) adalah segala keterangan, petunjuk, pengacuan yang berkaitan dengan tempat dan waktu dan suasana terjadinya peristiwa dalam cerita.

d. Sudut Pandang atau Point of View

Yang dimaksud titik pandang atau point of view adalah cara pengarang menampilkan para pelaku dalam cerita yang dipaparkan (Aminuddin 1987:90). Sudut pandang atau titik kisah ( point of view) adalah posisi pencerita (pengarang) terhadap kisah yang diceritakan (Wiyanto 2005:83). Point of view pada dasarnya adalah visi pengarang artinya sudut pandangan yang diambil pengarang untuk melihat suatu kejadian cerita (Sumardjo 1986:82). Selain itu Nurgiyantoro (2005: 248) juga menyebutkan bahwa sudut pandang pada hakikatnya merupakan strategi, teknik, dan siasat, yang secara sengaja dipilih pengarang untuk mengemukakan gagasan dan ceritanya.

Dari beberapa pendapat dapat peneliti simpulkan bahwa sudut pandang atau point of view adalah cara memandang yang digunakan pengarang sebagai sarana untuk menyajikan tokoh, tindakan latar, dan sebagai peristiwa yang membentuk cerita dalam sebuah cerita kepada pembaca.

e. Gaya

Gaya erat hubungannya dengan nada cerita. Gaya merupakan pemakaian bahasa yang spesifik dari seorang pengarang. Pengertian gaya dikemukakan oleh beberapa pengarang seperti yang 
tersebut berikut; "gaya bahasa adalah cara pengarang menggunakan bahasa untuk menghasilkan karya sastra"(Wiyanto 2005:84). Aminuddin (1987:72) mengemukakan bahwa gaya bahasa mengandung pengertian cara pengarang menyampaikan gagasannya dengan menggunakan media bahasa yang indah dan harmonis serta mampu menuansakan makna dan suasana yang dapat menyentuh daya intelektual dan emosi pembaca. Sehingga dapat disimpulkan bahwa gaya adalah keterampilan pengarang dalam mengolah dan memilih bahasa secara tepat dan sesuai dengan watak pikiran dan perasaan. Setiap pengarang mempunyai gaya yang berbeda-beda dalam mengungkapkan hasil karyanya.

f. Tema

Tema adalah ide cerita (Sumardjo 1986:56). Selanjutnya Suharianto (1982:28) mengatakan bahwa tema sering disebut juga dasar cerita; yakni pokok permasalahan yang mendominasi suatu karya sastra. Ia terasa dan mewarnai karya sastra tersebut dari halaman pertama hingga halaman terakhir. Hakikatnya tema adalah permasalahan yang merupakan titik tolak pengarang dalam menyusun cerita atau karya sastra tersebut, sekaligus merupakan permasalahan yang ingin dipecahkan pengarang dengan karyanya itu. Sehingga dapat disimpulkan bahwa yang dimaksud tema adalah ide atau gagasan atau permasalahan yang mendasari suatu cerita yang merupakan titik tolak pengarang dalam menyusun cerita atau karya sastra.

g. Amanat

Karya sastra selain berfungsi sebagai hiburan bagi pembacanya, juga berfungsi sebagai sarana pendidikan. Dengan kata lain, pengarang selain untuk menghibur pembaca (penikmat) juga ingin mengajari pembaca. Ajaran yang ingin disampaikan pengarang itu dinamakan amanat. Amanat adalah unsur pendidikan, terutama pendidikan moral, yang ingin disampaikan oleh pengarang kepada pembaca lewat karya sastra yang ditulisnya (Wiyanto 2005:84). Menurut Suharianto (1982:70) "amanat ialah nilai-nilai yang ada dalam cerita".

Dari beberapa pendapat tersebut dapat disimpulkan bahwa yang dimaksud dengan amanat adalah pesan yang ingin disampaikan pengarang kepada pembaca lewat karya sastra yang ditulisnya.

\section{Metode Latihan Terbimbing}

Mengajar adalah suatu usaha yang sangat kompleks, sehingga sulit menentukan bagaimana sebenarnya mengajar yang baik. Metode adalah cara yang berkaitan dengan pengorganisasian kegiatan belajar bagi warga belajar (Syamsu 1994:155). Sedangkan pembelajaran adalah suatu kegiatan yang dilakukan oleh guru sedemikian rupa sehingga tingkah laku siswa berubah ke arah yang lebih baik (Darsono 2000:24). Metode adalah salah satu alat untuk mencapai tujuan. Sedangkan metode mengajar adalah strategi pengajaran untuk mencapai tujuan yang diharapkan (Djamarah 2002: 84). Hal ini mendorong seorang guru untuk mencari metode yang tepat dalam penyampaian materinya agar dapat diserap dengan baik oleh siswa. Mengajar secara efektif sangat bergantung pada pemilihan dan penggunaan metode mengajar. Jadi dapat disimpulkan bahwa metode dalam pembelajaran adalah 
strategi pembelajaran yang digunakan oleh guru sebagai media untuk mencapai tujuan pembelajaran yang telah ditetapkan.

Pada penelitian ini peneliti menggunakan metode latihan terbimbing. Menurut peneliti metode latihan terbimbing adalah suatu cara mengajar yang baik digunakan untuk menanamkan kebiasaan-kebiasaan tertentu, sebagai sarana untuk memelihara kebiasaan-kebiasaan yang baik, dan juga digunakan untuk memperoleh suatu ketangkasan, kesempatan dan keterampilan dengan proses pemberian bantuan yang terus menerus dan sistematis kepada individu dalam memecahkan masalah yang dihadapinya agar tercapai keterampilan untuk dapat memahami dirinya, keterampilan untuk menerima dirinya, keterampilan untuk mengarahkan dirinya, dan keterampilan untuk merealisasikan dirinya sesuai dengan keterampilannya dalam mencapai penyesuaian diri dengan lingkungan, baik di dalam keluarga, sekolah dan masyarakat. Bimbingan dan arahan dilakukan oleh seseorang yang ahli dan berkompetensi di bidangnya.

Metode latihan terbimbing yang digunakan dalam proses pembelajaran akan menciptakan kondisi siswa yang aktif. Dalam menggunakan metode tersebut guru harus berhati-hati karena hasil dari suatu latihan terbimbing akan tertanam dan kemudian menjadi kebiasaan. Selain untuk menanamkan kebiasaan metode latihan terbimbing ini juga dapat menambah kecepatan, ketepatan dan kesempurnaan dalam melakukan sesuatu, serta dapat pula dipakai sebagai suatu cara untuk mengulangi bahan yang telah dikaji.

Untuk menunjang keberhasilan penggunaan metode latihan terbimbing dalam pembelajaran keterampilan Menulis Cerita Sederhana diperlukan guru yang benar-benar berkompetensi di bidangnya, dalam hal ini yaitu guru yang menguasai keterampilan mengajar dan menguasai sastra. Bimbingan adalah bantuan yang diberikan oleh seseorang, baik pria maupun wanita, yang terlatih dengan baik dan memiliki kepribadian dan pendidikan yang memadahi kepada seseorang, dari semua usia untuk membantunya mengatur kegiatan, keputusan sendiri, dan menanggung bebannya sendiri (Crow\&Crow dalam Mugiarso 2004:2). Kegiatan bimbingan bukan merupakan suatu kegiatan yang dilakukan secara kebetulan, insidental, sewaktu-waktu tidak sengaja, atau asal saja, melainkan suatu kegiatan yang dilakukan dengan sistematis, sengaja, berencana, terus-menerus dan terarah pada tujuan. Setiap kegiatan bimbingan merupakan kegiatan yang berkelanjutan artinya senantiasa diikuti secara terus menerus dan aktif sampai sejauh mana individu telah berhasil mencapai tujuan dan penyesuaian diri.

\section{Media Teks Lagu}

Media adalah alat bantu apa saja yang dapat dijadikan sebagai penyalur pesan guna mencapai tujuan pengajaran (Djamarah dan Zain 2002:137). Dalam proses belajar mengajar kehadiran media mempunyai arti yang cukup penting. Karena dalam kegiatan belajar mengajar ketidakjelasan bahan yang disampaikan dapat dibantu dengan menghadirkan media sebagai perantara. Secara umum fungsi media adalah sebagai penyalur pesan. Media pengajaran dapat mempertinggi proses belajar siswa dalam pengajaran yang pada gilirannya dapat mempertinggi hasil belajar yang dicapai (Sudjana dan 
Rivai 2001: 2). Selain itu, media pembelajaran dapat menambah efektivitas komunikasi dan interaksi antara guru dan siswa.

Penggunaan media harus sejalan dengan tujuan pengajaran yang telah dirumuskan. Manakala tujuan pembelajaran diabaikan dalam menggunakan media maka media bukan lagi sebagai alat bantu pengajaran tetapi sebagai penghambat dalam pencapaian tujuan secara efektif dan efisien. Penggunaan media dalam proses belajar mengajar juga dapat membangkitkan rasa ingin tahu dan minat, membangkitkan motivasi dan rangsangan dalam proses belajar mengajar, serta dapat mempengaruhi psikologi siswa. Oleh karena itu media dapat digunakan secara tepat, secara nyata membantu dan mempermudah proses belajar mengajar. Dengan demikian, hasil pembelajaran dapat lebih optimal.

Teks lagu adalah naskah yang berisi syair lagu yang merupakan ragam suara yang berirama. Lagu merupakan karya yang estetis yang bermakna dan mempunyai arti bukan hanya sesuatu yang kosong tanpa makna. Oleh karena itu sebelum mengkaji aspek-aspek yang lain perlu lebih dahulu dikaji lagu sebagai sebuah struktur yang bermakna dan bernilai estetis. Penciptaan lagu dapat memberikan kesenangan juga berharap bagi para penikmat dapat mengerti maksud yang terkandung dalam lagu tersebut yang merupakan jalinan komunikasi.

Suharto dalam Wardah (2005:37) mengungkapkan bahwa lagu adalah sarana informasi dan edukasi bagi negara dan bagi masyarakat. Sebagai sarana informasi yaitu lagu sebagai sarana penyampaian ungkapan hati atau ungkapan perasaan seorang penyair kepada pendengar. Sebagai sarana edukasi lagu dapat digunakan sebagai media dalam pembelajaran di sekolah karena lagu merupakan salah satu bentuk karya seni.

Teks lagu yang berisi syair lagu dapat dijadikan sebagai media pembelajaran Menulis Cerita Sederhana yaitu dengan menyoroti teks lagu tersebut dari tema dan alur. Dengan menyoroti dua hal tersebut media teks lagu dapat mempermudah siswa dalam mengembangkan ide, gagasan, atau perasaannya ke dalam sebuah karya sastra yang berupa cerpen

\section{METODE}

\section{Setting Penelitian}

Jenis penelitian yang dilakukan oleh peneliti yaitu penelitian tindakan kelas, yang lazim disebut PTK. Dengan demikian, penelitian ini sifatnya berbasis kelas, karena dilakukan dengan melibatkan komponen yang terdapat di dalam proses belajar mengajar di dalam kelas, materi pelajaran, dan metode pembelajaran

Tujuan dari penelitian ini tidak lain adalah untuk memperbaiki pembelajaran menulis dan meningkatkan kemampuan Menulis Cerita Sederhana siswa melalui metode latihan terbimbing dengan media teks lagu. Diharapkan dari penelitian ini hasil belajar dapat lebih maksimal.

Empat tahapan digunakan secara sistematis dalam proses penelitian ini, dan diterapkan dalam dua siklus, yaitu proses tindakan siklus I dan proses tindakan siklus II. Namun dalam hal ini, peneliti 
memerlukan kajian awal berupa renungan atau refleksi awal sebagai studi pendahuluan sebelum melakukan perencanaan penelitian. Hal ini dimaksudkan untuk mengetahui semua gejala atau informasi tentang situasi-situasi yang relevan dengan topik penelitian.

\section{Subjek Penelitian}

Penelitian ini dilaksanakan oleh penulis di SD Negeri Wonokusumo VII/46 Kecamatan Semampir Kota Surabaya. Pelaksanaan penelitian dan perbaikan dijadwalkan oleh penulis dengan jadwal sebagai berikut :

Tabel 1. Waktu Pelaksanaan

\begin{tabular}{|l|c|l|}
\hline No & Siklus & \multicolumn{1}{c|}{ Waktu Pelaksanaan } \\
\hline 1 & Siklus 1 & Selasa, 7 Agt 2018 \\
\hline 2 & Siklus 2 & Selasa, 14 Agt 2018 \\
\hline
\end{tabular}

Dalam penelitian tindakan kelas ini, subjek yang menjadi sasaran penelitian yaitu kemampuan Menulis Cerita Sederhana melalui metode latihan terbimbing dengan media teks lagu pada siswa Kelas III-A SD Negeri Wonokusumo VII/46 Surabaya. Penelitian ini hanya dilakukan di Kelas III-A, yang jumlahnya 40 siswa, yang terdiri atas 12 siswa putra, dan 28 siswa putri.

\section{Teknik Pengumpulan Data}

Adapun teknik pengumpulan data yang penulis gunakan dalam penelitian ini adalah teknik nontes dan teknik tes. Teknik nontes alat penilaian yang dipergunakan untuk mendapatkan informasi tentang keadaan di tertes (testi, tercoba, inggris testee) tanpa dengan alat tes. Teknik nontes diperlukan untuk mendapatkan data yang tidak, atau paling tidak secara langsung, berkaitan dengan laku kognitif. Teknik ini diterapkan melalui kegiatan observasi dan pengumpulan dokumentasi.

Adapun teknik tes adalah teknik yang dilakukan untuk memperoleh data dengan menggunakan tes. Tes dilakukan sebanyak dua kali, yaitu pada siklus I dan pada siklus II. Materi tes mengacu pada aspek-aspek Menulis Cerita Sederhana. Tes digunakan untuk mengukur dasar dan pencapaian prestasi (Arikunto, 2002:196). Hasil tes siklus I dianalisis tersebut dapat diketahui kelemahan siswa, yang selanjutnya sebagai dasar untuk melengkapi siklus II. Hasil siklus II dianalisis sehingga dapat diketahui peningkatan kemampuan Menulis Cerita Sederhana melalui latihan terbimbing dengan media teks lagu.

\section{Validasi Data}

Uji instrumen ini menggunakan validitas isi dan permukaan. Validitas isi adalah derajat tes yang menggambarkan esensi, topik-topik, dan ruang lingkup tes yang dirancang untuk pengukuran, (Sevilla dalam Hardani 2006:39). Validitas isi dilakukan dengan menyesuaikan aspek keterampilan Menulis Cerita Sederhana berdasarkan landasan teori yang ada.

Validitas permukaan (paras) adalah tipe validitas yang berkaitan dengan tipe tes. Tipe validitas ini tidak didukung oleh bukti-bukti bahwa tes tersebut dapat mengukur sesuatu (Sevilla 
dalam Hardani 2006:39). Validitas permukaan dilakukan dengan cara dikonsultasikan dengan dosen pembimbing dan guru., sehingga dari pendapat mereka dapat disepakati bahwa instrumen yang akan digunakan dalam penelitian sudah valid.

\section{Teknik Analisis Data}

Teknik analisa data menggunakan teknik analisis kuantitatif dan kualitatif. Analisis kuantitatif dilakukan untuk menganalisis data yang diperoleh dari hasil tes secara tertulis. Hasil analisis hasil tes secara kuantitatif dihitung secara persentase dengan langkah-langkah sebagai berikut:

a. Merekap nilai yang diperoleh siswa

b. Menghitung nilai masing-masing aspek

c. Menghitung nilai rata-rata,

d. Menghitung persentase nilai.

Nilai dihitung dengan menggunakan persen atau disebut percentages correction (Hardani 1997:41). Rumus-rumus penelitian adalah sebagai berikut:

$$
N P=\frac{R}{S M} \times 100
$$

NP : Nilai Persen yang Dicari

R : Skor Mental yang diperoleh siswa

SM : Skor Maksimum ideal dari Tes yang Bersangkutan

100 : Bilangan tetap

Hasil perhitungan kemampuan Menulis Cerita Sederhana melalui metode latihan terbimbing dengan media teks lagu dari masing-masing siklus ini kemudian akan dibandingkan. Hasil ini akan memberikan gambaran mengenai persentase peningkatan keterampilan Menulis Cerita Sederhana melalui latihan terbimbing dengan media teks lagu.

Sedangkan analisis data secara kualitatif dilakukan untuk menganalisis data nontes yang diperoleh dari siswa selama proses pembelajaran berlangsung. Untuk memperoleh data nontes dari responden, digunakan lembar angket, lembar pengamatan, dan pedoman wawancara. Responden memberikan jawaban sesuai dengan kriteria yang dilakukan peneliti.

Analisis data secara kualitatif dilakukan dengan langkah-langkah sebagai berikut:

a. Menelaah seluruh data yang diperoleh dari hasil nontes

b. Menyusun dalam satuan-satuan

c. Mengkategorisasikan

Analisis data secara kualitatif ini digunakan untuk mengetahui perubahan perilaku siswa dalam Menulis Cerita Sederhana pada siklus I dan siklus II. Selain itu data nontes juga digunakan untuk mengetahui tanggapan siswa terhadap metode pembelajaran yang digunakan. 


\section{Indikator Kinerja}

Indikator kinerja dalam penelitian ini sebagaimana terinci dalam tabel berikut :

Tabel 2. Skor Penilaian Tes Menulis Cerita Sederhana

\begin{tabular}{|c|c|}
\hline Aspek & Skor Maksimal \\
\hline Tema dan Amanat & 10 \\
\hline Tokoh dan Penokohan & 20 \\
\hline Alur & 20 \\
\hline Latar & 10 \\
\hline Diksi dan Gaya Bahasa & 10 \\
\hline Sudut Pandang & 10 \\
\hline Kepaduan Unsur Cerpen & 20 \\
\hline Jumlah & 100 \\
\hline
\end{tabular}

Adapun pedoman penilaian kemampuan menulis cerita sederhana dapat penulis jabarkan pada tabel berikut:

Tabel 3. Pedoman Penilaian Kemampuan Menulis Cerita Sederhana

\begin{tabular}{|c|c|c|}
\hline No & Nilai & Kategori \\
\hline 1 & $85-100$ & Sangat baik \\
\hline 2 & $75-84$ & Baik \\
\hline 3 & $60-74$ & Cukup \\
\hline 4 & $50-59$ & Kurang \\
\hline 5 & $0-49$ & Sangat kurang \\
\hline
\end{tabular}

Siswa yang berhasil sangat baik adalah siswa yang memperoleh nilai 85-100, siswa yang berhasil dengan baik adalah siswa yang memperoleh nilai 75-84, siswa yang berhasil dengan kategori cukup baik yaitu siswa yang memperoleh nilai 60-74, siswa yang berhasil dengan kategori kurang baik yaitu siswa yang memperoleh nilai 50-59, dan siswa yang tidak berhasil yaitu siswa yang memperoleh nilai $0-49$.

\section{Hasil dan Pembahasan}

Hasil

\section{Deskripsi Kondisi Awal}

Merujuk pada hasil observasi awal menunjukkan data bahwa keterampilan Menulis Cerita Sederhana pada siswa Kelas III-A SD Negeri Wonokusumo VII/46 Surabaya sudah termasuk ke dalam kategori cukup yaitu 61,30. Dari 40 siswa, 2 siswa atau sebesar 5\% termasuk ke dalam kategori baik, 25 siswa atau sebesar 62,5\% termasuk ke dalam kategori cukup, 11 siswa atau sebanyak 27,5\% termasuk ke dalam kategori kurang, 2 siswa atau sebanyak 5\% mendapat kategori sangat kurang. Walaupun sudah berada pada kategori cukup tetapi masih perlu adanya perbaikan untuk 
meningkatkan hasil nilai siswa.

Setelah melihat hasil tes pratindakan (keadaan awal) siswa yang telah dipaparkan, perlu dilakukan sebuah tindakan agar dapat meningkatkan keterampilan siswa dalam Menulis Cerita Sederhana. Tindakan yang dilakukan adalah berupa pembelajaran Menulis Cerita Sederhana melalui metode latihan terbimbing dengan media teks lagu.

\section{Deskripsi Siklus I}

Objek sasaran yang diamati dalam observasi siswa meliputi 8 perilaku positif dan 8 perilaku negatif. Adapun objek sasaran perilaku positif meliputi: (1) siswa memperhatikan penjelasan guru, (2) siswa banyak bertanya kepada guru, (3) siswa berpartisipasi aktif, (4) siswa dapat mengidentifikasi dan menyebutkan unsur-unsur yang ada dalam cerpen, (5) siswa merespon positif (senang) terhadap metode latihan terbimbing dengan media teks lagu, (6) siswa dapat Menulis Cerita Sederhana dengan senang hati, (7) siswa dapat Menulis Cerita Sederhana dengan cepat. Perilaku negatif meliputi: (1) siswa kurang merespon penjelasan guru, (2) siswa kurang bersemangat terhadap metode latihan terbimbing dengan media teks lagu, (3) siswa banyak bicara dan bergurau dengan temannya, (4) siswa pasif dalam pembelajaran, (5) siswa jalan-jalan/mondar-mandir pada saat pembelajaran berlangsung, (6) siswa kurang bersemangat dalam Menulis Cerita Sederhana, (7) siswa sangat lambat dalam Menulis Cerita Sederhana, (8) siswa enggan memberikan sanggahan terhadap pembacaan cerpen temannya.

Berdasarkan hasil pengamatan (observasi) peneliti pada saat pembelajaran pada siklus I, perilaku siswa yang terdeskripsi pada saat observasi menunjukkan sikap positif dan ada pula sikap yang negatif. Perilaku positif ditunjukkan oleh sikap siswa yang aktif mengikuti pembelajaran Menulis Cerita Sederhana, terlihat juga sebagian besar siswa merespon baik pembelajaran Menulis Cerita Sederhana dengan metode latihan terbimbing dengan media teks lagu. Perilaku negatif ditunjukkan dengan sikap masa bodoh dan kurang bersemangat mengikuti pembelajaran. Selain itu siswa melakukan kegiatan seperti bicara dan bergurau dengan temannya, serta jalan-jalan/mondarmandir pada saat pembelajaran berlangsung. Hal ini dapat dilihat dari hasil observasi, yang menunjukkan siswa banyak melakukan perilaku positif daripada perilaku negatif. Selama pembelajaran tidak semua siswa mengikuti pembelajaran dengan baik, tetapi masih ada beberapa siswa yang melakukan perilaku negatif. Namun, peneliti sadar akan hal ini karena setiap siswa memiliki karakteristik dan keterampilan yang berbeda. Apalagi, pola pembelajaran yang diterapkan peneliti merupakan hal baru bagi mereka sehingga perlu proses untuk menyesuaikannya.

Berdasarkan data observasi dapat dilihat jumlah siswa yang melakukan perilaku positif dan siswa yang melakukan perilaku negatif. Berdasarkan data yang diperoleh sebagian besar siswa atau sebanyak 34 siswa atau 85\% dari jumlah keseluruhan siswa memperhatikan penjelasan guru dengan baik. Sisanya sebanyak 6 siswa atau sebanyak 15\% dari jumlah keseluruhan siswa kurang merespon penjelasan guru. Siswa yang kurang merespon penjelasan guru, perilakunya bermacam-macam seperti memperhatikan keadaan di luar kelas, berbicara dan bergurau dengan temannya. 
Pada siklus I ini hanya ada 4 atau sebanyak 10\% dari jumlah keseluruhan siswa yang berani mengajukan pertanyaan kepada peneliti, sisanya sebanyak 36 siswa atau sebanyak $90 \%$ tidak berani bertanya kepada peneliti. Siswa yang kurang berani mengajukan pertanyaan pada guru ini perilakunya bermacam-macam seperti ada yang malu-malu ketika guru memberikan kesempatan pada siswa untuk bertanya. Ada yang masih kurang percaya diri, dan ada pula yang asyik berbicara sendiri dengan teman sebangkunya.

Sebanyak 27 siswa atau 67,5\% dari jumlah keseluruhan siswa aktif dalam mengikuti pembelajaran Menulis Cerita Sederhana dengan baik. Sisanya, sebanyak 13 siswa atau sebanyak 32,5\% dari jumlah keseluruhan siswa kurang aktif dalam mengikuti pembelajaran Menulis Cerita Sederhana. Siswa yang kurang aktif dalam mengikuti pembelajaran Menulis Cerita Sederhana disebabkan karena peneliti bukanlah guru yang biasa mengajar di kelas sehingga siswa masih merasa asing dengan guru (peneliti).

Sebanyak 32 siswa atau sebanyak $80 \%$ dari jumlah keseluruhan siswa aktif berpartisipasi menyebutkan unsur-unsur pembangun cerpen. Mereka secara aktif menyebutkan satu per satu unsurunsur pembangun cerpen dan mendefinisikannya, serta memberikan contoh-contohnya dengan bantuan guru. Sisanya 8 siswa atau sebanyak 8 siswa atau sebanyak 20\% dari jumlah keseluruhan siswa kurang aktif berpartisipasi menyebutkan unsur-unsur pembangun karya sastra. Hal tersebut disebabkan mereka kurang mengetahui unsur-unsur pembangun cerpen dan ada pula yang kurang mengikuti pembelajaran dengan baik.

Salah satu hal yang penting dalam penelitian ini adalah metode dan media yang digunakan oleh guru dalam pembelajaran Menulis Cerita Sederhana yaitu metode latihan terbimbing dengan media teks lagu. Dalam hal ini, sebagian besar siswa sebanyak 32 atau $80 \%$ dari jumlah keseluruhan siswa merespon positif metode yang digunakan oleh peneliti, mereka merasa senang karena mereka dapat bertanya-tanya kepada guru pada saat mengalami kesulitan dalam Menulis Cerita Sederhana. Media teks lagu yang dihadirkan oleh guru juga mendapat respon yang positif, sebagian besar dari jumlah keseluruhan siswa tersebut banyak yang menyukai lagu-lagu. Sisanya sebanyak 8 siswa atau $20 \%$ dari jumlah keseluruhan siswa yang kurang merespon metode dan media yang digunakan guru dalam Menulis Cerita Sederhana.

Berdasarkan data observasi dapat dilihat, sebanyak 31 siswa atau 77,5\% dari jumlah keseluruhan siswa dapat Menulis Cerita Sederhana dengan senang hati. Hal ini disebabkan karena mereka senang dengan media yang dihadirkan guru, selain mereka terhibur mereka juga dapat Menulis Cerita Sederhana. Selain itu juga mereka merasa dipermudah dalam Menulis Cerita Sederhana, teks lagu tersebut sudah ada sebagai kerangka karangan sehingga siswa hanya mengembangkan cerita berdasarkan teks lagu. Sisanya sebanyak 9 siswa atau 22,5\% dari jumlah keseluruhan siswa kurang senang Menulis Cerita Sederhana, hal ini disebabkan karena siswa kurang tertarik atau kurang senang Menulis Cerita Sederhana.

Sebanyak 7 siswa atau $17,5 \%$ dari jumlah keseluruhan siswa dapat mengerjakan atau dapat 
Menulis Cerita Sederhana dengan cepat. Tujuh siswa tersebut mampu menyelesaikan cerpen yang ditulisnya sebelum waktu yang ditentukan selesai. Hal ini disebabkan mereka sudah merasa mudah mengungkapkan ide dan mampu mengembangkan lirik yang berada dalam teks lagu. Sisanya 33 siswa atau $82,5 \%$ dari jumlah keseluruhan siswa belum dapat menyelesaikan cerpen yang dibuatnya dengan cepat.

Sebanyak 3 siswa atau sebesar 7,5\% dari jumlah keseluruhan siswa berani memberikan komentar terhadap hasil penulisan cerpen temannya yang dibacakan di depan kelas. 37 siswa atau sebesar 92,5\% kurang berani memberikan komentar terhadap hasil penulisan cerpen yang dibacakan di depan kelas. Hal tersebut disebabkan karena mereka malu atau kurang percaya diri berbicara di kelas, selain itu, mereka juga mempunyai pendapat yang sama dengan teman yang telah mengajukan pertanyaan sehingga mereka tidak memberikan komentarnya. Siswa yang menunjukkan sikap kurang berani memberikan komentar terhadap hasil penulisan cerpen yang dibacakan di depan kelas juga disebabkan karena mereka tidak memperhatikan pada saat temannya membacakan cerpen di depan kelas.

Meskipun proses pembelajaran dapat berjalan dengan lancar, tetapi masih ada beberapa siswa yang masih kurang tertib dalam mengikuti pembelajaran Menulis Cerita Sederhana. Sebanyak 11 siswa atau 27,5\% dari jumlah keseluruhan siswa banyak berbicara dan bergurau dengan temannya. Sisanya 29 siswa atau sebanyak 72,5\% dari jumlah keseluruhan siswa tertib dalam mengikuti pembelajaran Menulis Cerita Sederhana.

Sebanyak 8 siswa atau sebesar 20\% dari jumlah keseluruhan siswa sering jalan-jalan/mondarmandir pada saat proses pembelajaran berlangsung. Siswa tersebut melakukan kegiatan kurang positif seperti mengganggu temannya yang sedang serius Menulis Cerita Sederhana ataupun hanya sekadar meminjam alat tulis yang sebenarnya tidak begitu diperlukan. Sebanyak 14 siswa atau sebesar 35\% dan sering melihat pekerjaan temannya. Hal ini dilakukan ketika merasa bingung untuk memulai Menulis Cerita Sederhana pada saat tes Menulis Cerita Sederhana berlangsung.

Berdasarkan pada uraian di atas, meskipun jumlah siswa yang melakukan perilaku positif lebih banyak daripada perilaku negatif, tetapi pembelajaran Menulis Cerita Sederhana di kelas ini perlu ditingkatkan lebih baik lagi. Guru harus berupaya agar siswa lebih aktif dan perilaku negatif yang muncul pada siklus I ini dapat dikurangi pada siklus berikutnya.

\section{Deskripsi Siklus II}

Berdasarkan pengamatan peneliti, secara keseluruhan proses pembelajaran Menulis Cerita Sederhana pada siklus II ini dapat dikatakan baik karena jumlah siswa yang melakukan perilaku negatif telah berkurang. Pada siklus II, terdapat beberapa perilaku siswa yang terdeskripsi melalui kegiatan observasi. Selama melakukan kegiatan pembelajaran Menulis Cerita Sederhana melalui metode latihan terbimbing dengan media teks lagu, guru (peneliti) merasakan adanya perubahan pada prilaku siswa. Pada saat guru menjelaskan materi tentang cerpen, sebagian siswa menunjukkan perilaku yang positif dalam mengikuti pembelajaran Menulis Cerita Sederhana melalui metode latihan 
terbimbing dengan media teks lagu. Berdasarkan data yang diperoleh sebagian besar siswa atau sebanyak 38 siswa atau sebesar 95\% dari jumlah keseluruhan siswa memperhatikan penjelasan guru dengan baik. Sisanya sebanyak 2 siswa atau sebesar 5\% dari jumlah keseluruhan siswa kurang merespon penjelasan guru. Dari jumlah ini berarti terjadi peningkatan siswa yang berperilaku positif. Siswa yang memperhatikan penjelasan guru berdasarkan pengamatan peneliti siswa yang memperhatikan merupakan siswa yang pada siklus I mendapat nilai baik, tetapi ada juga beberapa siswa yang pada siklus I kurang memperhatikan di siklus II ini memperhatikan penjelasan guru. Siswa yang aktif bertanya pada siklus II ini sebanyak 7 siswa atau sebesar 17,5\% dari jumlah keseluruhan siswa dan yang tidak berani mengajukan pertanyaan kepada peneliti yaitu sebanyak 33 siswa atau sebesar $82,5 \%$ dari jumlah keseluruhan siswa. Siswa yang kurang berani mengajukan pertanyaan kepada guru disebabkan kurang percaya diri, dan ada pula yang memang sudah paham dengan materi Menulis Cerita Sederhana.

Sebanyak 36 siswa atau sebesar 90\% dari jumlah keseluruhan siswa yang aktif dalam mengikuti pembelajaran Menulis Cerita Sederhana melalui metode latihan terbimbing dengan media teks lagu. Sisanya sebanyak 4 siswa atau sebesar 10\% dari jumlah keseluruhan siswa yang tidak aktif dalam mengikuti pembelajaran Menulis Cerita Sederhana. Mereka asyik bercanda dengan teman sebangkunya dan enggan mempelajari teks lagu yang diberikan oleh guru sebagai media dalam membelajarkan Menulis Cerita Sederhana.

Seperti halnya pada siklus I, hal yang paling penting dalam penelitian ini adalah metode yang digunakan oleh guru dalam membelajarkan mengenai Menulis Cerita Sederhana. Sebagian besar siswa atau sebanyak 37 atau sebesar 92,5\% dari jumlah keseluruhan siswa yang merespons positif metode yang digunakan oleh peneliti, mereka merasa senang dapat bertanya langsung dengan guru mengenai kesulitan-kesulitan siswa dalam Menulis Cerita Sederhana. Siswa lebih akrab dengan peneliti karena pada siklus II ini merupakan pertemuan untuk ketiga kalinya sehingga siswa tidak lagi merasa asing dengan guru. Sisanya 3 siswa atau sebesar 7,5\% dari jumlah keseluruhan siswa yang merasa kurang senang dengan metode yang digunakan guru karena seolah-olah mereka begitu diawasi oleh guru sehingga merasa cemas dan malu apabila yang dituliskannya salah. Dari data tersebut berarti terjadi peningkatan siswa yang melakukan perilaku positif.

Dari data observasi dapat dilihat terjadinya peningkatan perilaku positif siswa dalam Menulis Cerita Sederhana. Data tersebut menunjukkan bahwa sebanyak 38 siswa atau sebesar 95\% dari jumlah keseluruhan siswa yang merasa lebih bersenang hati dalam Menulis Cerita Sederhana. Sisanya sebanyak 2 siswa atau sebesar 5\% yang kurang bersenang hati dalam Menulis Cerita Sederhana. Hal ini disebabkan siswa kurang berminat dalam Menulis Cerita Sederhana.

Sebanyak 13 siswa atau sebesar 32,5\% dari jumlah keseluruhan siswa yang dapat dengan cepat menyelesaikan tugas Menulis Cerita Sederhananya dengan baik. Hal ini disebabkan karena mereka lebih terbiasa Menulis Cerita Sederhana dan lebih mudah menuangkan kata-kata ke dalam cerpen. Sisanya 27 siswa atau sebesar $67,5 \%$ dari jumlah keseluruhan siswa yang kurang begitu cepat 
dalam menyelesaikan tugas Menulis Cerita Sederhana. Namun mereka dapat menyelesaikan tugas tersebut dengan tepat sesuai dengan waktu yang ditentukan.

Dalam memberikan komentar terhadap pembacaan cerpen temannya di depan kelas pada siklus II ini juga mengalami peningkatan. Pada siklus II ini sebanyak 5 siswa atau sebesar 12,5\% dari jumlah keseluruhan siswa yang berani memberikan komentar terhadap pembacaan cerpen milik temannya. Sisanya sebanyak 35 siswa atau $87 \%$ dari jumlah keseluruhan siswa kurang berani memberikan komentar terhadap hasil penulisan cerpen temannya. Hal tersebut disebabkan siswa kurang berani mengungkapkan pendapatnya mengenai cerpen.

Proses pembelajaran Menulis Cerita Sederhana melalui metode latihan terbimbing dengan media teks lagu dapat berjalan dengan lancar. Siswa yang pada siklus I melakukan perilaku negatif dalam siklus II ini lebih banyak berperilaku positif. Suasana kelas terlihat lebih tertib daripada pada siklus yang ke II. Siswa yang berperilaku negatif seperti sering bergurau dengan temannya, berbicara dengan temannya, serta siswa yang sering mondar-mandir atau berjalan jalan pada saat pembelajaran Menulis Cerita Sederhana berlangsung berkurang. Sebanyak 2 siswa atau sebesar 5\% dari jumlah keseluruhan siswa yang bergurau dan berbicara dengan teman sebangkunya. Sisanya sebesar 38 siswa atau sebesar 95 dari jumlah keseluruhan siswa. Dan siswa yang melakukan perilaku negatif yaitu mondar-mandir atau jalan-jalan tanpa tujuan yang jelas tidak ada.

Berdasarkan uraian di atas menunjukkan bahwa terjadinya peningkatan perilaku siswa dalam mengikuti proses pembelajaran pada siklus II ini. Perilaku-perilaku negatif siswa dapat dikurangi sehingga pembelajaran ini dapat berhasil.

\section{Pembahasan}

Sebelum pembelajaran Menulis Cerita Sederhana melalui metode latihan terbimbing dengan media teks lagu dilakukan, terlebih dahulu dilakukan tes pratindakan. Tes ini dilakukan dengan tujuan untuk mengetahui kondisi awal keterampilan siswa Kelas III-A SD Negeri Wonokusumo VII/46 Surabaya dalam Menulis Cerita Sederhana. Hasil pratindakan ini dianalisis dan diperoleh sebuah simpulan bahwa keterampilan Menulis Cerita Sederhana siswa Kelas III-A SD Negeri Wonokusumo VII/46 Surabaya masih kurang memuaskan. Hal ini ditunjukkan dengan nilai rata-rata yang diperoleh siswa sebesar 61,30. Keterampilan siswa dalam menentukan tema dan amanat, membuat alur, menentukan tokoh dan penokohan, menentukan latar, menggunakan diksi dan gaya bahasa, menentukan sudut pandang, dan keterpaduan unsur-unsur dalam cerpen termasuk dalam kategori cukup.

Setelah peneliti melihat kondisi awal keterampilan siswa Menulis Cerita Sederhana melalui hasil pratindakan tersebut, maka peneliti melakukan pembelajaran Menulis Cerita Sederhana melalui metode latihan terbimbing dengan media teks lagu. Setelah dilakukan pembelajaran Menulis Cerita Sederhana melalui metode latihan terbimbing dengan media teks lagu pada siklus I, keterampilan menulis Cerita Sederhana siswa mengalami peningkatan sebesar 11,94\%. Nilai rata-rata yang dicapai pada siklus I sebesar 68,62 yang berarti bahwa pada siklus I keterampilan Menulis Cerita Sederhana 
siswa sudah cukup baik. Hal ini juga ditandai dengan peningkatan penguasaan aspek tema dan amanat sebesar 1,35\%, peningkatan penguasaan aspek alur sebesar 1,12\%, peningkatan penguasaan aspek tokoh dan penokohan, sebesar 1,93, peningkatan penguasaan aspek latar sebesar 0,20\%, peningkatan penguasaan aspek diksi dan gaya bahasa sebesar 0,43\%, peningkatan penguasaan aspek sudut pandang sebesar $0,20 \%$, dan peningkatan penguasaan aspek kepaduan unsur-unsur pembangun cerpen sebesar $1,70 \%$. Meskipun pembelajaran siklus I telah dioptimalkan perencanaan dan pelaksanaannya melalui metode latihan terbimbing dengan media teks lagu, namun hasil tes yang diperoleh siswa pada siklus ini belum memuaskan dan belum memenuhi target. Hal ini karena sebagian besar siswa masih mengalami kesulitan Menulis Cerita Sederhana terutama dalam mengembangkan kerangka cerpen yang ada dalam teks lagu dan menuangkan ide yang ada dalam pikiran mereka.

Pada hasil pratindakan, skor rata-rata kelas mencapai 63,19 termasuk dalam kategori cukup. Skor rata-rata ini berasal dari jumlah rata-rata masing-masing aspek yang dinilai. Pada pratindakan, perolehan nilai rata-rata kelas aspek tema dan amanat sebesar 65 (termasuk kategori cukup), aspek alur sebesar 58,9 (termasuk kategori kurang), aspek tokoh dan penokohan sebesar 58,75 (termasuk kategori kurang), aspek latar sebesar 70,3 (termasuk kategori cukup), aspek diksi dan gaya bahasa sebesar 61,5 (termasuk kategori cukup), aspek sudut pandang sebesar 71 (termasuk kategori cukup), dan aspek kepaduan unsur-unsur pembangun cerpen sebesar 63,19 (termasuk kategori cukup). Keterampilan siswa dalam Menulis Cerita Sederhana masih rendah disebabkan oleh dua faktor yaitu faktor internal dan faktor eksternal. Faktor internal ini dapat dilihat pada keterampilan siswa dalam aspek bahasa dan nonkebahasaan yang masih kurang. Hal ini dapat dilihat pada hasil tes yang belum menunjukkan hasil yang memuaskan (belum mencapai kategori baik). Adapun faktor eksternal berasal dari pola pembelajaran guru yang masih tradisional dan kurang bervariasi. Pola pembelajaran yang lebih mengutamakan teori, ceramah, monoton, dan terkesan hanya mengejar materi pelajaran tanpa pertimbangan pengalaman yang akan didapatkan siswa dalam pembelajaran.

Selanjutnya, hasil tes Menulis Cerita Sederhana siklus I dengan rata-rata skor klasikal mencapai 69,7 dan termasuk kategori cukup. Hasil ini mengalami peningkatan sebesar 7,32\% dari hasil pratindakan. Meskipun hasil ini sudah mengalami peningkatan, tetapi nilai rata-rata ini belum mencapai target nilai yang telah ditetapkan. Skor ini juga diperoleh dari penjumlahan tujuh aspek penilaian. Perolehan aspek tema dan amanat sebesar 78,5 (termasuk kategori baik), aspek alur sebesar 67,5 (termasuk kategori cukup), aspek tokoh dan penokohan sebesar 68,4 (termasuk kategori baik), aspek latar sebesar 72,3 (termasuk kategori cukup), aspek diksi dan gaya bahasa sebesar 65,8 (termasuk kategori cukup), aspek sudut pandang sebesar 73 (termasuk kategori cukup), dan aspek kepaduan unsur-unsur pembangun cerpen sebesar 65,4 (termasuk kategori baik). Adapun peningkatan tiap aspek penilaian siklus I terhadap nilai rata-rata tiap aspek penilaian pratindakan yaitu (1) aspek tema dan amanat meningkat sebesar 20,77\% dari skor pratindakan, (2) aspek alur meningkat sebesar 9,51\% dari skor pratindakan, (3) aspek tokoh dan penokohan meningkat sebesar 16,43\% dari skor pratindakan, (4) aspek latar meningkat sebesar 2,84\% dari skor pratindakan, (5) aspek diksi dan gaya 
bahasa meningkat sebesar 6,99\% dari skor pratindakan, (6) aspek sudut pandang meningkat sebesar $2,82 \%$ dari skor pratindakan, dan aspek kepaduan unsur-unsur pembangun cerpen meningkat sebesar $14,94 \%$ dari skor pratindakan.

Nilai pada aspek Menulis Cerita Sederhana siswa Kelas III-A SD Negeri Wonokusumo VII/46 Surabaya semua mengalami peningkatan dari hasil pratindakan. Pada aspek tema dan amanat, siswa sudah bisa mengaplikasikan tema dan amanat berdasarkan teks lagu yang digunakan sebagai media sudah cukup baik, walaupun ada beberapa siswa yang menyimpang dari tema yang telah ada dalam teks lagu. Pada aspek alur siswa sudah banyak mengalami peningkatan karena alur dalam Menulis Cerita Sederhana sudah ada, jadi siswa lumayan tidak mengalami kesulitan. Aspek tokoh dan penokohan siswa juga sudah dapat menghadirkan tokoh dengan karakternya yang menarik, namun masih ada beberapa siswa yang belum bisa menghadirkan tokoh dengan karakternya yang menarik. Pada aspek latar siswa sudah dapat menentukan latar yang cocok sesuai dengan situasi dan kondisi dalam cerpen yang ditulisnya. Pada aspek diksi dan gaya bahasa siswa sudah dapat menggunakan kata-kata yang sesuai dengan konteksnya. Pada aspek sudut pandang siswa sudah bisa menggunakan kata ganti untuk menjelaskan tokoh dengan baik. Pada aspek yang terakhir yaitu kepaduan unsurunsur pembangun cerpen siswa sudah cukup baik dalam Menulis Cerita Sederhana, terbukti dengan hasil cerpen yang cukup menarik.

Berdasarkan pada uraian di atas, peningkatan skor rata-rata dari pratindakan ke siklus I yang paling besar yaitu pada aspek yang kedua yaitu alur. Hal ini terjadi karena pembuatan alur dalam Menulis Cerita Sederhana berdasarkan teks lagu yang digunakan sebagai media dalam metode latihan terbimbing pembelajaran Menulis Cerita Sederhana. Adapun peningkatan skor rata-rata dari pratindakan ke siklus I yang paling kecil yaitu pada aspek sudut pandang, hal ini disebabkan siswa mengabaikan aspek ini dan menganggapnya mudah.

Berikutnya, pada hasil tes Menulis Cerita Sederhana siklus II, diperoleh nilai rata-rata kelas 78,8 dan termasuk dalam kategori baik. Pencapaian skor ini menunjukkan bahwa pembelajaran Menulis Cerita Sederhana pada siswa Kelas III-A SD Negeri Wonokusumo VII/46 Surabaya dapat dikatakan berhasil karena sudah mencapai target yaitu berada pada kategori baik. Dengan demikian tindakan siklus III, tidak perlu dilakukan.

Perolehan skor aspek tema dan amanat sebesar 81,8 (termasuk kategori baik), aspek alur sebesar 76,5 (termasuk kategori baik), aspek tokoh dan penokohan sebesar 70,75 (termasuk kategori baik), aspek latar sebesar 86,5 (termasuk kategori baik), aspek diksi dan gaya bahasa sebesar 79,5 (termasuk kategori baik), aspek sudut pandang sebesar 84,8 (termasuk kategori baik), dan aspek kepaduan unsur-unsur pembangun cerpen sebesar 71,75 (termasuk kategori cukup). Adapun peningkatan tiap aspek penilaian siklus II terhadap nilai rata-rata tiap aspek penilaian siklus I yaitu (1) aspek tema dan amanat meningkat sebesar 4,20\% dari skor siklus I, (2) aspek alur meningkat sebesar 18,60\% dari skor siklus I, (3) aspek tokoh dan penokohan meningkat sebesar 3,44\% dari skor siklus I, (4) aspek latar meningkat sebesar 19,64\% dari skor siklus I, (5) aspek diksi dan gaya bahasa 
meningkat sebesar 20,82\% dari skor siklus I, (6) aspek sudut pandang meningkat sebesar 16,16\% dari skor siklus I, dan aspek kepaduan unsur-unsur pembangun cerpen meningkat sebesar 12,29\% dari skor siklus I. Peningkatan skor rata-rata siklus I ke siklus II yang paling besar yaitu pada aspek diksi dan gaya bahasa. Hal ini disebabkan karena pada siklus II ini siswa sudah mulai terbiasa mengungkapkan idenya dan imajinasinya ke dalam cerpen, mereka semakin terampil menggunakan kata-kata serta gaya bahasa yang tepat dalam Menulis Cerita Sederhana. Adapun peningkatan skor rata-rata siklus I ke siklus II yang paling kecil yaitu pada aspek tokoh dan penokohan hal ini disebabkan pada siklus I nilai tokoh dan penokohan sudah berada pada kategori baik, jadi peningkatan pada siklus II tidak terlalu besar.

Peningkatan keterampilan siswa dalam Menulis Cerita Sederhana merupakan bukti bahwa pembelajaran Menulis Cerita Sederhana melalui metode latihan terbimbing dengan media teks lagu dapat meningkatkan kualitas, kreativitas, prestasi dan efektivitas pembelajaran siswa dalam menulis cerita pendek serta dapat meningkatkan apresiasi sastra siswa khususnya terhadap karya sastra yang berupa cerpen.

Pembahasan selanjutnya yaitu mengenai perubahan perilaku siswa dalam mengikuti proses pembelajaran Menulis Cerita Sederhana melalui metode latihan terbimbing dengan media teks lagu pada siklus I dan siklus II. Perubahan perilaku tersebut diperoleh dari observasi, jurnal, wawancara dan dokumentasi foto, yang dipaparkan dalam uraian di bawah ini.

Dari hasil nontes yaitu melalui observasi dapat dilihat bahwa pada siklus I siswa belum mengikuti proses pembelajaran Menulis Cerita Sederhana dengan baik, masih ada beberapa siswa yang melakukan perilaku negatif walaupun jumlahnya lebih sedikit daripada siswa yang melakukan perilaku positif dalam mengikuti proses pembelajaran tersebut. Hal ini dibuktikan dengan data pada hasil observasi siswa yang tercatat ada 11 atau sebesar 27,5\% dari jumlah keseluruhan siswa yang berbicara dan bercanda dengan temannya pada saat proses pembelajaran Menulis Cerita Sederhana. Sebanyak 8 siswa atau sebesar 20\% dari jumlah keseluruhan siswa yang mondar-mandir atau jalanjalan untuk kepentingan yang tidak jelas pada saat proses pembelajaran berlangsung.

Pada siklus II sudah ada perubahan perilaku siswa yaitu siswa sudah mengikuti proses pembelajaran Menulis Cerita Sederhana dengan baik dan dapat menciptakan suasana belajar yang nyaman. Siswa terlihat sangat bersungguh-sungguh dalam mengikuti penjelasan dari guru, dan mereka sudah lebih aktif dalam mengikuti pelajaran dibandingkan pada siklus I. Perilaku negatif pada siklus I, pada siklus II banyak berkurang. Siswa yang melakukan perilaku negatif berbicara dan bercanda dengan temannya menurun dari 11 siswa atau sebesar 27,5\% dari jumlah keseluruhan siswa menjadi 2 siswa atau sebesar 5\% dari jumlah keseluruhan siswa. Sedangkan siswa yang berjalan-jalan atau mondar-mandir pada saat berlangsungnya proses pembelajaran tidak ada.

Berdasarkan hasil penelitian dari siklus I ke siklus II diperoleh siswa semakin senang terhadap metode latihan terbimbing dengan media teks lagu yang dihadirkan guru (peneliti). Menurut sebagian besar dari jumlah siswa Kelas III-A SD Negeri Wonokusumo VII/46 Surabaya yang 
menyatakan bahwa metode tersebut dapat mempermudah mereka dalam Menulis Cerita Sederhana karena kesulitan-kesulitan yang mereka hadapi dapat diatasi dengan metode tersebut.

Berdasarkan hasil angket dari siklus I ke siklus II diperoleh hasil bahwa sebagian dari jumlah keseluruhan siswa menyatakan setuju bahwa metode latihan terbimbing dengan media teks lagu dalam Menulis Cerita Sederhana sangat menyenangkan dan dapat meningkatkan kreativitas siswa dalam Menulis Cerita Sederhana. Selain itu metode tersebut juga dapat memotivasi dan menumbuhkan minat bagi siswa untuk Menulis Cerita Sederhana.

Berdasarkan hasil wawancara didapatkan hasil bahwa siswa senang dan tertarik dengan pembelajaran Menulis Cerita Sederhana melalui metode latihan terbimbing dengan media teks lagu. Siswa juga dapat mengambil manfaat dari pembelajaran tersebut, siswa semakin tahu banyak tentang cerpen dan bagaimana Menulis Cerita Sederhana. Selain itu pembelajaran Menulis Cerita Sederhana melalui metode latihan terbimbing dengan media teks lagu siswa semakin berminat Menulis Cerita Sederhana.

Berdasarkan hasil dokumen foto siklus I ke siklus II yaitu siswa semakin tertib dan aktif dalam mengikuti pembelajaran Menulis Cerita Sederhana melalui metode latihan terbimbing dengan media teks lagu. Dari hasil foto (gambar 3) menunjukkan aktivitas saat Menulis Cerita Sederhana pada siklus I, terlihat masih ada siswa yang melakukan perilaku negatif yaitu bercanda dengan temannya saat proses belajar di kelas, sedangkan pada siklus II yang ditunjukkan pada gambar 6, siswa terlihat sangat serius dalam Menulis Cerita Sederhana. Berdasarkan kedua gambar tersebut dapat disimpulkan bahwa perilaku negatif siswa dalam mengikuti pembelajaran Menulis Cerita Sederhana mengalami peningkatan.

Dari uraian di atas dapat disimpulkan bahwa belajar Menulis Cerita Sederhana melalui metode latihan terbimbing dengan media teks lagu mampu meningkatkan keterampilan siswa dalam Menulis Cerita Sederhana. Selain itu, terdapat perubahan perilaku yaitu dari perilaku negatif ke perilaku positif siswa dalam mengikuti proses pembelajaran menulis cerita pendek.

\section{KESIMPULAN}

Berdasarkan paparan hasil penelitian dan pembahasan, dapat disimpulkan bahwa keterampilan Menulis Cerita Sederhana siswa Kelas III-A SD Negeri Wonokusumo VII/46 Surabaya mengalami peningkatan sebesar 20,44\% setelah mengikuti pembelajaran Menulis Cerita Sederhana melalui metode latihan terbimbing dengan media teks lagu. Hasil rata-rata tes Menulis Cerita Sederhana pratindakan sebesar 61 (hasil pembulatan ke bawah dari 61,30) dan pada siklus I diperoleh hasil ratarata sebesar 69 (hasil pembulatan ke atas dari 68,62) kemudian pada siklus II diperoleh hasil rata-rata sebesar 77 (hasil pembulatan ke bawah dari 77,05) atau meningkat sebesar 15,75\% dari siklus I. Perolehan hasil rata-rata nilai tes Menulis Cerita Sederhana ini menunjukkan bahwa pembelajaran Menulis Cerita Sederhana melalui metode latihan terbimbing dengan media teks lagu pada siswa Kelas III-A SD Negeri Wonokusumo VII/46 Surabaya dapat meningkat dan berhasil. 
Perilaku siswa Kelas III-A SD Negeri Wonokusumo VII/46 Surabaya setelah mengikuti pembelajaran Menulis Cerita Sederhana melalui metode latihan terbimbing dengan media teks lagu mengalami perubahan ke arah positif. Perubahan tersebut ditunjukkan dengan perilaku siswa yang lebih serius dan bersemangat dalam mengikuti proses pembelajaran Menulis Cerita Sederhana.

Berdasarkan simpulan hasil penelitian tersebut, peneliti memberikan saran agar guru bahasa dan sastra Indonesia dapat menggunakan metode latihan terbimbing dengan media teks lagu dalam membelajarkan Menulis Cerita Sederhana kepada siswa karena metode latihan terbimbing dengan media teks lagu dapat meningkatkan keterampilan siswa dalam Menulis Cerita Sederhana dan dapat memotivasi siswa untuk menulis cerita sederhana.

\section{UCAPAN TERIMA KASIH}

Terimakasih kami ucapkan kepada Bapak/Ibu Kepala Sekolah dan Guru-guru di SDN Wonokusumo VII/46 Surabaya yang telah memberikan kesempatan kepada peneliti dalam melaksanakan penelitian. Terimakasih kepada siswa yang telah ikut berpartisipasi dalam melaksanakan penelitian ini

\section{REFERENSI}

Aminuddin. 1987. Pengantar Apresiasi Karya Sastra. Bandung: Sinar Baru Algensindo Arikunto, Suharsimi. 2004. Prosedur Penelitian. Yogyakarta: Rineka Cipta

Darsono, Max 2001. Belajar dan Pembelajaran. Jakarta: Grasindo

Diknas 2005. Kurikulum Pendidikan Dasar. Jakarta: Diknas

Diponegoro, Mohammad. 1994. Yuk, Nulis Cerpen Yuk. Yogyakarta: Pustaka Pelajar

Djamarah, Syaiful Bahri. 1996. Strategi Belajar Mengajar. Jakarta: Erlangga

Endraswara, Suwardi. 2003. Membaca, Menulis, Mengajarkan Sastra. Yogyakarta: Kota Kembang Gie, The Liang. 2002. Terampil Mengarang. Yogyakarta:ANDI

Jabrohim, dkk. 2003. Cara Menulis Kreatif. Yogyakarta: Pustaka Pelajar

Mugiarso. 2004. Bimbingan Konseling. Semarang: UNNES Press

Nana, Sudjana dan Ahmad Rivai. 2002. Media Pengajaran. Bandung: Sinar Baru Algensindo

Nurgiantoro, Burhan. 1994. Teori Pengkajian Fiksi. Yogyakarta: Gadjah Mada University Press

Suharianto, S. 1982. Dasar-Dasar Teori Sastra. Surakarta: Widya Duta

Sumardjo, Jakob dan Saini K.M. 1986. Apresiasi Kesusastraan. Jakarta: Gramedia

Sugiyono. 2003. Statistika Untuk Penelitian. Bandung: Alfabeta

Suyatno. 2004. Teknik Pembelajaran Bahasa dan Sastra. Kota Surabaya: SIC

Syamsu, Maopa. 1994. Teori Belajar Orang Dewasa. Jakarta: Departemen Pendidikan dan

Kebudayaan

Tarigan, Henry Guntur. 1985. Menulis Sebagai Suatu Keterampilan Berbahasa. Bandung: Angkasa Titik, dkk. 2003. Teknik Menulis Cerita Anak. Yogyakarta: PUSBUK 
Wardah, Hilma. 2005. Wacana Lirik Lagu Aksi Pergerakan Mahasiswa Kajian Diksi, Makna dan Fungsi. Skripsi: UNNES 